\title{
Content Learning Indicator in Equivalence Checking between Skills Module and Academic Module for APEL Process
}

\author{
https://doi.org/10.3991/ijet.v14i20.11459 \\ Amin N.F.M M $\left({ }^{\varpi}\right)$, N. Kaprawi \\ Universiti Tun Hussein Onn Malaysia, Johor, Malaysia \\ Farhah zai@yahoo.com
}

\begin{abstract}
Accreditation of Prior Experiential Learning (APEL) is an accreditation system involving assessment of a person's recognition of experience through formal, informal and non-formal learning. Generally, APEL provides opportunity for individuals to gain access to higher learning institutions and gain credits in learning based on experience gained through equivalence checking. Therefore, this study aimed at obtaining feedback/input on items for nine (9) content learning indicator domains that will be used for the determination of learning content in assessing the equivalence checking between the skills module and the academic module for the APEL process. The nine (9) domains are knowledge (current) in the field; practical skills; social skills \& accountability; values, attitudes \& professionalism; communication skills, leadership \& teamwork; problem solving skills \& scientific skills; management skills, entrepreneurship \& innovation; information management \& lifelong learning; and interdisciplines. This study uses a quantitative approach which uses questionnaire to get feedback from respondents. A total of 32 respondents comprising lecturers from seven (7) faculties of Universiti Tun Hussein Onn Malaysia. The data are analysed using Statistical Packages for Social Science 23.0 (SPSS 23.0). The finding of this study found that all the items in the Content Learning Indicator in equivalence checking between skills module and academic module of the APEL process are very appropriate. Improvements are made such as feedback and recommendations provided by respondents.
\end{abstract}

Keywords-Accreditation of Prior Experiential Learning (APEL); Equivalence Checking; Content Learning Indicator

\section{Introduction}

This study aimed to enhance the development and strengthen APEL systems in Malaysia with the construction of a structured evaluation tool that can determine the learning content of a module for equivalence checking between skills and academic. This is due to difficulties for individuals that have skills to put themselves in the academic program. These individuals have to undergo very high admission requirements set by the university even though they have extensive experience skills. Thus, they 
have to start from the foundation. They also have to take a long learning time because of previous learning knowledge is not recognised. Hence, the equivalence checking between skills and academic is a development of relevant qualification mobility.

It is also a requirement to be applied due to its necessity to be taken seriously and be given opportunities to those in this area of skills to pursue their studies at the academic level. According to [1] individuals with this experience should not take the same amount of credit hours as individuals who are just following the study without any experience and skills. This is because the experience and skills of the individuals are the same as the lessons learned later. So with APEL, the repetition of learning can be reduced rather than having to take all the subjects and reduced to only some necessary subjects.

[2] States that Malaysia's Qualification Framework is indispensable for the merger of technical and vocational skills levels along with qualification descriptions. The problem that arises for this situation is to recognise the possessed experience and skills that require a complete description so that equivalence can be done more systematically. Hence, a study on the development of previous learning credential frameworks should be implemented to be the key path for individuals with the experience to connect with higher learning in Malaysia. In this study, researchers have developed a preliminary framework for structured evaluation tools that can determine the learning content of a module for equivalence checking between skills and academic.

\section{Literature Review}

\subsection{Accredition of prior experential learning (APEL)}

Generally, different terms have been adopted in different countries to clarify activities related to accreditation/recognition of previous learning contexts. For example, Accreditation of Prior Learning (United Kingdom); Recognition of Prior Learning (Australia, South Africa, Scotland and Ireland); Recognition of Current Competency (New Zealand); Prior Learning Assessment and Recognition (Canada); and Prior Learning Assessment (United States). All of these terms involve the notion that prior learning should be recognised irrespective of how and where it is obtained, as long as learning is relevant to learning outcomes or competencies in a subject or program of study. In [3] previous learning means knowledge, skills or attitudes previously acquired and include past experience.

According to [4] APEL is a method of assessment where students can gain recognition for knowledge, understanding, skills and competencies they already have. It is also a process of formal recognition of learning gained from formal, personal and experiential learning. This process requires active thinking and experience analysis and self-assessment profile to extract the learning achieved for measuring learning outcomes. They may use this formal accreditation or endorsement to enter a study program at the usual entry qualification or for a part of the last qualification (e.g diploma or degree) to prevent them repeating the learning they have mastered. Accord- 
ing to [5] many countries have taken steps to improve the articulation of vocational education with higher education to unlock more options for students. There are two approaches to prior learning accreditation as follows:

- Accreditation of Prior Certificated Learning (APCL) assesses course/qualification learning outcomes in vocational education and vocational training. The question is the extent to which the learning outcomes of continuing vocational training certificates/qualifications are equivalent to the desired learning outcomes, results of competence or standards in the qualification of a particular course of study or in higher education. The main feature is that the trip or qualification is verified for equivalence, not the student. APCL can be described as a process, where previous studies are assessed, certified and considered as appropriate, recognised for academic purposes [6].

- Accreditation of Prior Experiential Learning (APEL) involves the assessment of case-by-case knowledge, skills and competencies of individuals that can be derived from a variety of learning experiences, including workplace learning, life experience and voluntary work. The key feature is APEL assessing individual competence. APEL can be described as a process, where learning is achieved beyond the educational system or training is assessed and, where appropriate, is recognised for academic purposes. In other words, individual competence is given recognition and academic value [7].

\subsection{Equivalence checking}

Past experience-based learning needs to be recognised regardless of how and where it is obtained as long as the learning is related to learning outcomes and competencies. Evaluation should be based on evidence, equal, without prejudice, fair, flexible, legitimate and credible. Subsequent evaluations should be conducted by a specialist or practitioner for subject matter or skill areas, policies and procedures. Additionally, the assessment methodology should contain the level of literacy and student's experience, thus providing the ways for students to demonstrate learning outcomes which are required.

Furthermore, information and support services need to be promoted actively, easily understood and identify the diversity of students' abilities. Finally, equivalent checking mechanisms should be clear and transparent to ensure confidence in the decision. However, for credit transfer process, recognition of past learning or previous experience from skills to academic, an implementation of equivalent checking is needed. Nowadays, no identifiable instrument can be used in the implementation of equivalence checking between the skills and academic. For example in German, equivalence checking process requires the assessor to assess the content and qualifications of the vocational or skills with the academic, based on their respective national qualification frameworks [8]. 


\subsection{Domain Indicator}

Module Learning Indicator (MLI): Module Learning Indicator (MLI) is a benchmark used to determine the module level based on the European Qualification Framework (EQF) [9] as its reference. In addition, MLI also compares between national qualification modules based on the learning outcomes that have been stated. Table 2.1 is on the domains in the Module Learning Indicator.

Table 1. Module Learning Indicator (MLI) [8]

\begin{tabular}{|c|c|c|c|}
\hline No. & Domain & Description & Example \\
\hline 1. & $\begin{array}{l}\text { Broad and up-to-date } \\
\text { knowledge. }\end{array}$ & $\begin{array}{l}\text { Describe the scope, depth and the } \\
\text { latest knowledge in the skills deliv- } \\
\text { ered in the learning unit. }\end{array}$ & $\begin{array}{l}\text { Contains in-depth inventory. } \\
\text { The module consists of at least some in- } \\
\text { depth inventory of knowledge that art in } \\
\text { the field of expertise. }\end{array}$ \\
\hline 2. & $\begin{array}{l}\text { Critical understand- } \\
\text { ing. }\end{array}$ & $\begin{array}{l}\text { Explain how far the theories, models } \\
\text { and methods that are part of the } \\
\text { learning unit give a critical situation. }\end{array}$ & $\begin{array}{l}\text { The module delivers awareness about } \\
\text { the limitations of the acquired skills and } \\
\text { knowledge. }\end{array}$ \\
\hline 3. & Interdisciplinary. & $\begin{array}{l}\text { Explain how far certain learning } \\
\text { units have to do with other profes- } \\
\text { sions or disciplines. Additionally, } \\
\text { explains how far it is able to teach } \\
\text { students to address the challenges } \\
\text { faced in the context of discipline. }\end{array}$ & $\begin{array}{l}\text { Modules consist of interdisciplinary } \\
\text { problem statements which resolution is } \\
\text { based on the application of knowledge } \\
\text { from various disciplines. }\end{array}$ \\
\hline 4. & Problem solving. & $\begin{array}{l}\text { Explain the study and evaluation of } \\
\text { learning success are related to real } \\
\text { claims of practice and practical } \\
\text { problems. }\end{array}$ & $\begin{array}{l}\text { Learning requirements and accordingly, } \\
\text { exam assignments require comprehen- } \\
\text { sive application of cognitive and practi- } \\
\text { cal skills. }\end{array}$ \\
\hline 5. & Practical relevance. & $\begin{array}{l}\text { Explain how students are faced with } \\
\text { complex problems in learning units } \\
\text { and their methods solve inde- } \\
\text { pendently through cognitive and/or } \\
\text { practical application. }\end{array}$ & $\begin{array}{l}\text { The module provides knowledge and } \\
\text { skills that can be used directly in prac- } \\
\text { tice. }\end{array}$ \\
\hline 6. & Innovation. & $\begin{array}{l}\text { Explain the method for assessing the } \\
\text { learning success of student learning } \\
\text { units faced with different situations } \\
\text { where problems require creative } \\
\text { approaches to find solutions. }\end{array}$ & $\begin{array}{l}\text { Learning needs include the development } \\
\text { of new strategic approaches. }\end{array}$ \\
\hline 7. & Autonomy. & $\begin{array}{l}\text { Describe the scope of independence } \\
\text { and responsibility of students in } \\
\text { learning units. }\end{array}$ & $\begin{array}{l}\text { Learning needs require free and proac- } \\
\text { tive action. }\end{array}$ \\
\hline 8. & Communication. & $\begin{array}{l}\text { Explain how to communicate infor- } \\
\text { mation, ideas, problems and solution } \\
\text { approaches to colleagues from the } \\
\text { same field, field experts and socie- } \\
\text { ties. }\end{array}$ & $\begin{array}{l}\text { Students have proven that they are able } \\
\text { to communicate their understanding of } \\
\text { their area of expertise to other individu- } \\
\text { als. }\end{array}$ \\
\hline 9. & $\begin{array}{l}\text { Consideration of } \\
\text { social and ethical } \\
\text { issues. }\end{array}$ & $\begin{array}{l}\text { Explain how the student takes into } \\
\text { consideration social and ethical } \\
\text { issues being chosen as the main } \\
\text { theme in the learning unit. }\end{array}$ & $\begin{array}{l}\text { When solving the problem, the students } \\
\text { show the consideration of others and the } \\
\text { unity with the people who may be af- } \\
\text { fected by their actions. }\end{array}$ \\
\hline
\end{tabular}

Domain Learning Outcomes: The learning outcome from Malaysian Qualification Framework (MQF) [10] determines the knowledge, skills and value obtained by the student when completed one program of study. The brief description of each do- 
main of learning outcomes within the Malaysian Qualifications Framework is in Table 2.2 below:

Table 2. Description of 8 domain of learning outcomes

\begin{tabular}{|c|c|c|}
\hline Domain & Description & Examples of Student Learning Outcomes \\
\hline Knowledge & $\begin{array}{l}\text { Demonstrate knowledge and under- } \\
\text { standing of the fundamental principles } \\
\text { of a field derived from advanced } \\
\text { textbooks and at the knowledge } \\
\text { boundaries. }\end{array}$ & $\begin{array}{l}\text { i. Recall/state facts and information; } \\
\text { ii. Distinguish objects and concepts; } \\
\text { iii. Demonstrate relationship between con- } \\
\text { cepts; } \\
\text { iv. Applying principles to new situations; } \\
\text { v. Explain situation; } \\
\text { vi. Make conclusions about causes or effects; } \\
\text { vii. Predict output results. }\end{array}$ \\
\hline Practical skills & \begin{tabular}{|l|} 
Demonstrate skill of performing \\
practical and technical tasks required \\
in field science (e.g. science lab skills, \\
engineering technical skills, clinical \\
skills, computer literacy and other IT \\
instruments).
\end{tabular} & $\begin{array}{l}\text { i. Conduct blood tests; } \\
\text { ii. Carry out first aid; } \\
\text { iii. Using power point for presentation. }\end{array}$ \\
\hline $\begin{array}{l}\text { Social skills and } \\
\text { responsibilities }\end{array}$ & $\begin{array}{l}\text { Demonstrate understanding and sensi- } \\
\text { tivity to diversity in society and will- } \\
\text { ing to work together to achieve com- } \\
\text { mon goals. }\end{array}$ & $\begin{array}{l}\text { i. Recall/state facts and information on various } \\
\text { cultural practices; } \\
\text { ii. Respect for cultural diversity and willing to } \\
\text { address and resolve socio-cultural issues in } \\
\text { society; } \\
\text { iii. Participate actively in ethnic activities and } \\
\text { community projects aimed at understanding } \\
\text { better inter-cultural and community develop- } \\
\text { ment. }\end{array}$ \\
\hline $\begin{array}{l}\text { Value, attitude and } \\
\text { professionalism }\end{array}$ & $\begin{array}{l}\text { Be able to use knowledge and under- } \\
\text { standing with methods that demon- } \\
\text { strate professionalism in work (com- } \\
\text { mon \& non-personal interests), pure } \\
\text { personality and relevant ethical deci- } \\
\text { sion-making. }\end{array}$ & $\begin{array}{l}\text { i. Collaborate in group learning as a team, } \\
\text { share knowledge and help each other; } \\
\text { ii. Demonstrate commitment to excellence, } \\
\text { confidentiality, honesty and integrity in Intel- } \\
\text { lectual Property; } \\
\text { iii. Commitment to scientific methods and } \\
\text { evidence-based decisions with ethical consid- } \\
\text { erations (fair, objective, reliable, transparent). }\end{array}$ \\
\hline $\begin{array}{l}\text { Information man- } \\
\text { agement and life- } \\
\text { long learning skills }\end{array}$ & $\begin{array}{l}\text { Having the techniques and capabilities } \\
\text { to find and use data to improve ideas, } \\
\text { problem solving and decision-making } \\
\text { and have learning skills to pursue } \\
\text { further studies with high autonomy. }\end{array}$ & $\begin{array}{l}\text { i. Can set reasonable learning objectives; } \\
\text { ii. Can use library and ICT to: } \\
\text { a. Find information } \\
\text { b. Keep records on a regular basis } \\
\text { c. Find information easily for reference } \\
\text { iii. Can teach others and give feedback. }\end{array}$ \\
\hline $\begin{array}{l}\text { Problem solving } \\
\text { skills and scientific } \\
\text { skills }\end{array}$ & $\begin{array}{l}\text { Exhibit scientific approach to solve } \\
\text { problems. }\end{array}$ & $\begin{array}{l}\text { i. Can apply the problem solving process in } \\
\text { learning: } \\
\text { a. Generating hypotheses } \\
\text { b. Ask relevant questions } \\
\text { c. Identify gaps in their own knowledge, skills } \\
\text { and values } \\
\text { d. Identify types and sources of information } \\
\text { e. Find and collect new data and information } \\
\text { f. Critically assess new information (evidence- } \\
\text { based) } \\
\text { g. Synthesise data from multiple sources. }\end{array}$ \\
\hline $\begin{array}{l}\text { Communication } \\
\text { skills, leadership } \\
\text { and teamwork }\end{array}$ & $\begin{array}{l}\text { Efficiently communicates and deliver } \\
\text { information, ideas, problems and } \\
\text { solutions to experts and non-experts as }\end{array}$ & $\begin{array}{l}\text { i. Demonstrate group-based learning skills in } \\
\text { the classroom and other activities with: } \\
\text { a. Listening, speaking, teaching, giving and }\end{array}$ \\
\hline
\end{tabular}




\begin{tabular}{|c|c|c|}
\hline & $\begin{array}{l}\text { well as having teamwork, leadership } \\
\text { and interpersonal skills appropriate to } \\
\text { the job. }\end{array}$ & $\begin{array}{l}\text { receiving feedback, teamwork, respecting } \\
\text { dissent } \\
\text { ii. Can use Malay and English language } \\
\text { properly in: } \\
\text { a. Conversations, take note of oral and non- } \\
\text { verbal signals; } \\
\text { b. Synthesise information and write essays and } \\
\text { other assignments; } \\
\text { c. Make an idea presentation to experts and } \\
\text { non-experts. }\end{array}$ \\
\hline $\begin{array}{l}\text { Management skills } \\
\text { and entrepreneur- } \\
\text { ship }\end{array}$ & $\begin{array}{l}\text { Utilise management \& business prin- } \\
\text { ciples to start entrepreneurship and } \\
\text { efficiently manage time and self to } \\
\text { face challenges. }\end{array}$ & $\begin{array}{l}\text { i. Can provide a business plan; } \\
\text { ii. Participate actively in student entrepreneuri- } \\
\text { al activities; } \\
\text { iii. Able to lead a student organisation or } \\
\text { student activity; } \\
\text { iv. Can take care of yourself, manage time and } \\
\text { face stress. }\end{array}$ \\
\hline
\end{tabular}

\section{$3 \quad$ Methodology}

\subsection{Research design}

This study uses a quantitative approach which adopts questionnaire to get feedback from respondents. [11] states that questionnaire can help to get consistent study responses. In this study, the researcher used survey method. Survey study is one of the most popular research methods used in various fields, especially in the field of social science. According to [12] survey studies are used to collect information from predetermined population samples. In addition, [13] stated that survey is a method that uses questionnaires or interviews as a research instrument depending on the type of required information.

\subsection{Population and sampling}

A total of 32 respondents comprises of lecturers from seven (7) Faculty of Universiti Tun Hussein Onn Malaysia is surveyed. The population of 32 respondents in this study consists of Dean, Deputy Dean and Head of Departments from faculties at Universiti Tun Hussein Onn Malaysia as stated below:

- Faculty of Civil and Environmental Engineering;

- Faculty of Electrical and Electronic Engineering;

- Faculty of Mechanical and Manufacturing Engineering;

- Faculty of Technical and Vocational Education;

- Faculty of Computer Science and Information Technology;

- Faculty of Engineering Technology;

- Faculty of Technology Management and Business.

Purposive sampling was selected for this study because the sample was selected from one population according to the purpose of the study due to the limited number 
of the respondents. According to [12] a packet is intended to involve individual considerations for selecting samples, based on researcher's knowledge and specific research purposes. For this study, the sample is comprised of individuals who are directly involved in the field of skills and academic education.

\subsection{Instrument of study}

The instrument that is used to get the data from the respondents in this study is a questionnaire. In social science research, the research instrument is usually a questionnaire designed to collect research data as it has many uses [13] The use of the questionnaire is appropriate given the limited time and the respondents are not influenced by the behavior of the researcher. According to [11] the questionnaire was used in this study to get a more consistent answer. The questionnaire is divided into 10 parts:

- A: Demographics

- B: Knowledge (Current) in the Field

- C: Practical Skills

- D: Social Skills and Accountability

- E: Values, Attitudes and Professionalism

- F: Communication Skills, Leadership and Teamwork

- G: Problem Solving Skills and Scientific Skills

- H: Skill Management, Entrepreneurship and Innovation

- I: Information Management and Lifelong Learning

- J: Interdiscipline

The questionnaire was developed using two approaches, namely the question of choice and likert scale. The items in this questionnaire are based on the benchmark findings from the Module Level Indicator (MLI) User Guide Assessment of the Level of Competence Orientation, the Australian Qualification Framework (AQF), the European Qualifications Framework (EQF) and the Malaysian Qualifications Framework (MQF) issued by the Malaysian Qualifications Agency (MQA). In addition, the questionnaire consists of nine parts. Part $\mathrm{A}$ is a multi-choice question to get the respondents' demographic information. In this part, the questions are on the institution, level of education, work experience and respondents' posts. Furthermore, sections B, C, D, E, F, G, H, I and J are to identify items that can be used as indicators for knowledge (current); practical skills; social skills \& accountability; values, attitudes \& professionalism; communication, leadership \& teamwork skills; problem solving \& scientific skills; management, entrepreneurship \& innovation skills; information management \& lifelong learning; and interdisciplines. The format for the questionnaires is shown in Table 3.1: 
Table 3. Questionnaires Format

\begin{tabular}{|l|c|c|}
\hline \multicolumn{1}{|c|}{ Domain } & No. Item & Total \\
\hline Knowledge (Current) & B1- B18 & 18 \\
\hline Practical Skills & C1- C5 & 5 \\
\hline Social Skills \& Accountability & D1-D8 & 8 \\
\hline Values, Attitudes \& Professionalism & E1-E5 & 5 \\
\hline Communication, Leadership \& Teamwork Skills & F1-F10 & 10 \\
\hline Problem Solving \& Scientific Skills & G1-G8 & 8 \\
\hline Management, Entrepreneurship \& Innovation Skills & H1-H12 & 12 \\
\hline Information Management \& Lifelong Learning & I1-I5 & 5 \\
\hline Interdisciplines & J1-J4 & 4 \\
\hline
\end{tabular}

\subsection{Validity and Reliability of Instruments}

This sub topic specifies the validity and reliability of instruments used in this study. The results showed that the value of reliability is obtained based on alpha Cronbach value for this study which was 0.920 . According to [14] this value states that the builtin instrument is in excellent and effective condition with a high level of consistency and it can be applied to the actual study. Table 3.2 is a table of alpha Cronbach score values and reliability level.

Table 4. Score of alpha Cronbach score and reliability level

\begin{tabular}{|c|l|}
\hline Alpha- Cronbach Score & \multicolumn{1}{c|}{ Reliability } \\
\hline $0.8-1.0$ & Very good and effective with high degree of consistency \\
\hline $0.7-08$ & Good and acceptable \\
\hline $0.6-0.7$ & Acceptable \\
\hline$<0.6$ & Item needs repair \\
\hline$<0.5$ & Item needs to be dropped \\
\hline
\end{tabular}

Researchers have set the alpha Cronbach values at 0.65 to 0.95 which can be considered satisfactory because the low value indicates the ability of the instrument to measure the concept in the study is too low, while too high alpha value may indicate that all items are similar or overlapping with each other. It is also noted by [11] which states that the level of reliability is determined using the alpha Cronbach range where the range of values is between 0.0 and 1.0. If the alpha coefficient approximates 1.0 shows the level of validity and reliability is high. If the alpha coefficient is less than 0.6 , then the validity and reliability of the instrument are low and need to be fixed.

\subsection{Data analysis method}

The data were analysed using Statistical Packages for Social Science 23.0 (SPSS 23.0). The level of agreement on the item is assessed and compared to the mean value obtained. This is to determine if the item reaches expert consensus to remain or to be dropped. Table 3.3 shows the stage of consensus on the item [15]. While Table 3.4 
shows the mean score Interprets for each indicator. These two tables are very important to determine the abandonment of the item.

Table 5. The level of consensus on the item

\begin{tabular}{|c|l|}
\hline Inter Quartile Range (IQR) Score & \multicolumn{1}{c|}{ Consensus Stage } \\
\hline $0-1$ & High Consensus \\
\hline $1.01-1.99$ & A moderate Consensus \\
\hline$\geq 2$ & No Consensus \\
\hline
\end{tabular}

Source: [15]

Table 6. Interpretation of the mean scores for each indicator

\begin{tabular}{|c|l|}
\hline Scale Range & \multicolumn{1}{|c|}{ Interpretation of Mean Score } \\
\hline $1.00-2.49$ & Low \\
\hline $2.50-3.49$ & Moderate \\
\hline $3.50-5.00$ & High \\
\hline
\end{tabular}

Source: [16] Adaptation

\section{$4 \quad$ Results and Findings}

\subsection{Data analysis}

The data analysis was made in the form of descriptive analysis which included the mean value, median and Inter quartile range. The 23.0 version of IBM Statistical Packages for the Social Sciences (SPSS) is used to analyse the data of this pilot study. Table 4.1 shows findings of the pilot study Indicator of Learning Content for Equivalence Checking between Skills and Academic in APEL process.

Table 7. Findings of the pilot study Indicator of Learning Content for Equivalence Checking between Skills and Academic in APEL process

\begin{tabular}{|c|c|c|c|c|}
\hline No. & Indicators / Items & Mean & Median & $\begin{array}{l}\text { Consensus } \\
\text { levels }\end{array}$ \\
\hline \multicolumn{5}{|c|}{ DOMAIN OF FIELD KNOWLEDGE (CURRENT) } \\
\hline \multicolumn{5}{|c|}{ The content of learning modules ... } \\
\hline B1 & Exceeding basic knowledge in the area of discipline. & 3.97 & 4.00 & $*$ \\
\hline B2 & $\begin{array}{l}\text { Contains facts, principles, methods and concepts of the } \\
\text { subject. }\end{array}$ & 3.75 & 4.00 & $*$ \\
\hline B3 & Equipped with various theories in the area of discipline. & 3.84 & 4.00 & $*$ \\
\hline B4 & Includes specific knowledge. & 4.03 & 4.00 & **** \\
\hline B5 & Almost the same as contained in the reference book. & 3.38 & 4.00 & $* *$ \\
\hline B6 & Covers the current aspect. & 4.00 & 4.00 & $* * *$ \\
\hline B7 & $\begin{array}{l}\text { Covers the knowledge that is equivalent to the } \\
\text { knowledge acquired in the latest research. }\end{array}$ & 3.88 & 4.00 & $* *$ \\
\hline B8 & Includes new findings in the area of discipline. & 3.53 & 4.00 & $* * *$ \\
\hline B9 & $\begin{array}{l}\text { Includes an observational report or research findings } \\
\text { based on the theory and model in the field of discipline. }\end{array}$ & 3.34 & 4.00 & $* *$ \\
\hline B10 & Lists some suggestions for developing and empirically & 3.59 & 4.00 & $* * *$ \\
\hline
\end{tabular}




\begin{tabular}{|c|c|c|c|c|}
\hline & test the theory and methodology. & & & \\
\hline B11 & $\begin{array}{l}\text { Providing alternative approaches or theories that help in } \\
\text { the area of discipline even as against each other. }\end{array}$ & 3.47 & 4.00 & $* * *$ \\
\hline $\mathrm{B} 12$ & $\begin{array}{l}\text { States topics or things that cannot be applied using a } \\
\text { theory or model. }\end{array}$ & 3.65 & 4.00 & $* * *$ \\
\hline B13 & $\begin{array}{l}\text { Raising awareness about knowledge boundaries in the } \\
\text { field. }\end{array}$ & 3.59 & 4.00 & $* * *$ \\
\hline B14 & $\begin{array}{l}\text { Provides a critical understanding of theories and princi- } \\
\text { ples relevant to disciplines. }\end{array}$ & 3.63 & 4.00 & $* * *$ \\
\hline \multicolumn{5}{|c|}{ ASSESSMENT AND EXAMINATION } \\
\hline B15 & $\begin{array}{l}\text { Students' knowledgeable of some theory or model in the } \\
\text { area of discipline. }\end{array}$ & 3.94 & 4.00 & $* * *$ \\
\hline B16 & $\begin{array}{l}\text { Students are aware of current developments in disci- } \\
\text { pline. }\end{array}$ & 4.03 & 4.00 & $* *$ \\
\hline B17 & $\begin{array}{l}\text { Students demonstrate the theory and principles of disci- } \\
\text { pline studied critically. }\end{array}$ & 3.88 & 4.00 & $*$ \\
\hline B18 & $\begin{array}{l}\text { Students know the historical development of theories, } \\
\text { models or technic of disciplines. }\end{array}$ & 3.93 & 4.00 & $* *$ \\
\hline \multicolumn{5}{|c|}{ DOMAIN OF PRACTICAL SKILLS } \\
\hline \multicolumn{5}{|c|}{ Learning content and methods } \\
\hline $\mathrm{C} 1$ & $\begin{array}{l}\text { Equipped with theories and described models based on } \\
\text { examples of practical situations. }\end{array}$ & 3.88 & 4.00 & $*$ \\
\hline $\mathrm{C} 2$ & $\begin{array}{l}\text { Assists in the preparation of processes and procedures } \\
\text { for the implementation of practical tasks/work. }\end{array}$ & 3.78 & 4.00 & $* * *$ \\
\hline $\mathrm{C} 3$ & $\begin{array}{l}\text { Able to provide skills that can be applied immediately in } \\
\text { training/practical. }\end{array}$ & 3.78 & 4.00 & $* * *$ \\
\hline \multicolumn{5}{|c|}{ ASSESSMENT AND EXAMINATION } \\
\hline $\mathrm{C} 4$ & $\begin{array}{l}\text { The module covers a solution to the real practical prob- } \\
\text { lem. }\end{array}$ & 3.97 & 4.00 & $* *$ \\
\hline $\mathrm{C} 5$ & $\begin{array}{l}\text { Students demonstrate their ability to solve the practical } \\
\text { problems faced. }\end{array}$ & 3.75 & 4.00 & $* * *$ \\
\hline \multicolumn{5}{|c|}{ DOMAIN OF SKILLS \& SOCIAL RESPONSIBILITIES } \\
\hline \multicolumn{5}{|c|}{ Learning content and methods } \\
\hline D1 & $\begin{array}{l}\text { Establishing a team working relationship in terms of } \\
\text { cooperation in achieving consensus on an issue. }\end{array}$ & 3.66 & 4.00 & $* * *$ \\
\hline D2 & $\begin{array}{l}\text { Covers the development of self-confidence for account- } \\
\text { ability and trust in community activities. }\end{array}$ & 3.69 & 4.00 & $* *$ \\
\hline D3 & Train students to interact with others. & 3.66 & 4.00 & **** \\
\hline D4 & $\begin{array}{l}\text { Includes self-consciousness which consists of the man- } \\
\text { agement of emotions and attitudes and good behavior. }\end{array}$ & 3.53 & 4.00 & $* * *$ \\
\hline D5 & \begin{tabular}{|l|l} 
Includes reflection on ethical or social issues. \\
\end{tabular} & 3.84 & 4.00 & **** \\
\hline \multicolumn{5}{|c|}{ ASSESSMENT AND EXAMINATION } \\
\hline D6 & $\begin{array}{l}\text { Students can consider the ethical effects learned from } \\
\text { the theories, models and methods of discipline. }\end{array}$ & 3.84 & 4.00 & $* * *$ \\
\hline D7 & $\begin{array}{l}\text { Students take into account the ecological effects and } \\
\text { care of the environment. }\end{array}$ & 3.50 & 4.00 & $* * *$ \\
\hline D8 & $\begin{array}{l}\text { Students can engage in analysing and monitoring the } \\
\text { social norms. }\end{array}$ & 3.75 & 4.00 & $* * *$ \\
\hline \multicolumn{5}{|c|}{ DOMAIN OF VALUES, ATTITUDES \& PROFESSIONALISM } \\
\hline \multicolumn{5}{|c|}{ ASSESSMENT AND EXAMINATION } \\
\hline $\mathrm{E} 1$ & $\begin{array}{l}\text { Students can practice good values in all circumstances } \\
\text { and situations. }\end{array}$ & 4.00 & 4.00 & $* * *$ \\
\hline E2 & Students show self-reliance in performing tasks. & 3.74 & 4.00 & $* * *$ \\
\hline
\end{tabular}




\begin{tabular}{|c|c|c|c|c|}
\hline E3 & $\begin{array}{l}\text { Students carry out given assignments according to the } \\
\text { scope of work that meets expectations. }\end{array}$ & 3.84 & 4.00 & $* * *$ \\
\hline E4 & $\begin{array}{l}\text { Students perform a task honestly, sincerely and trans- } \\
\text { parently. }\end{array}$ & 3.45 & 4.00 & $* * *$ \\
\hline E5 & $\begin{array}{l}\text { Students make good working culture. (ethical, efficient, } \\
\text { productive and prudent). }\end{array}$ & 3.42 & 4.00 & $* * *$ \\
\hline \multicolumn{5}{|c|}{ DOMAIN OF COMMUNICATION SKILLS, LEADERSHIP \& TEAMWORK } \\
\hline \multicolumn{5}{|c|}{ The content of learning modules ... } \\
\hline $\mathrm{F} 1$ & $\begin{array}{l}\text { Includes oral communication skills, written communica- } \\
\text { tion, leadership and teamwork. }\end{array}$ & 3.45 & 4.00 & *** \\
\hline $\mathrm{F} 2$ & $\begin{array}{l}\text { Contains the methods and ways of communicating clear } \\
\text { and convincing ideas. }\end{array}$ & 3.81 & 4.00 & $* * *$ \\
\hline F3 & $\begin{array}{l}\text { Provide procedures for producing systematic clarity, } \\
\text { continuity and writing. }\end{array}$ & 3.74 & 4.00 & $* * *$ \\
\hline $\mathrm{F} 4$ & $\begin{array}{l}\text { Reveals knowledge and understanding of effective } \\
\text { leadership. }\end{array}$ & 3.74 & 4.00 & $* * *$ \\
\hline F5 & $\begin{array}{l}\text { Helps students to build good relationships and team- } \\
\text { work among team members to achieve the same objec- } \\
\text { tives. }\end{array}$ & 3.45 & 4.00 & $* * *$ \\
\hline \multicolumn{5}{|c|}{ ASSESSMENT AND EXAMINATION } \\
\hline F6 & $\begin{array}{l}\text { Students are fluent to communicate their understanding } \\
\text { to other students. }\end{array}$ & 3.77 & 4.00 & $* * *$ \\
\hline F7 & $\begin{array}{l}\text { Students can communicate about the methods they use } \\
\text { for problem solving to other students. }\end{array}$ & 3.71 & 4.00 & $* * *$ \\
\hline F8 & $\begin{array}{l}\text { Students exchange opinions with experts and the com- } \\
\text { munity about information, ideas, problems and solu- } \\
\text { tions. }\end{array}$ & 3.45 & 4.00 & $* * *$ \\
\hline F9 & $\begin{array}{l}\text { Students convey information, ideas, problems and } \\
\text { solutions to experts. }\end{array}$ & 3.71 & 4.00 & $* * *$ \\
\hline $\mathrm{F} 10$ & $\begin{array}{l}\text { Students demonstrate the ability to exchange opinions } \\
\text { with the community regarding information, ideas, } \\
\text { problems and solutions. }\end{array}$ & 3.58 & 4.00 & $* * *$ \\
\hline \multicolumn{5}{|c|}{ DOMAIN OF SKILLS SOLUTIONS \& SCIENTIFIC SKILLS } \\
\hline \multicolumn{5}{|c|}{ ASSESSMENT AND EXAMINATION } \\
\hline G1 & $\begin{array}{l}\text { Students can solve specific problems from subject } \\
\text { modules. }\end{array}$ & 3.94 & 4.00 & $*$ \\
\hline G2 & Students do writing exercises on complex questions. & 3.55 & 4.00 & $* * *$ \\
\hline G3 & $\begin{array}{l}\text { Students practice deep cognitive thinking as well as } \\
\text { practical skills. }\end{array}$ & 3.48 & 4.00 & $* * *$ \\
\hline G4 & Students can meet the latest needs and requirements. & 3.55 & 4.00 & $*$ \\
\hline G5 & $\begin{array}{l}\text { Students are able to assess the effectiveness of the } \\
\text { solutions they have developed. }\end{array}$ & 3.90 & 4.00 & * \\
\hline G6 & $\begin{array}{l}\text { Students are able to make comparative decisions be- } \\
\text { tween existing information, ideas and solutions. }\end{array}$ & 3.97 & 4.00 & * \\
\hline G7 & $\begin{array}{l}\text { Students can generate new ideas that are potential and } \\
\text { practical to be implemented. }\end{array}$ & 4.00 & 4.00 & $* * *$ \\
\hline G8 & $\begin{array}{l}\text { Students need to consolidate existing ideas to produce } \\
\text { new and efficient problem solving. }\end{array}$ & 3.68 & 4.00 & $* * *$ \\
\hline \multicolumn{5}{|c|}{ DOMAIN OF MANAGEMENT SKILLS, ENTREPRENEURSHIP \& INNOVATION } \\
\hline \multicolumn{5}{|c|}{ The content of the learning module } \\
\hline H1 & $\begin{array}{l}\text { Contains clear business ideas and meet customer } \\
\text { needs/requirements. }\end{array}$ & 3.77 & 4.00 & $* * *$ \\
\hline $\mathrm{H} 2$ & $\begin{array}{l}\text { Have risk management procedures with the right chan- } \\
\text { nels. }\end{array}$ & 3.84 & 4.00 & $*$ \\
\hline
\end{tabular}




\begin{tabular}{|c|c|c|c|c|}
\hline $\mathrm{H} 3$ & Lists basic financial components and resources. & 3.87 & 4.00 & $*$ \\
\hline $\mathrm{H} 4$ & Possesses financial planning and resources for cost. & 3.90 & 4.00 & $*$ \\
\hline H5 & $\begin{array}{l}\text { Possesses ways/methods for doing business globally by } \\
\text { strategy and meet the requirements/needs of the client. }\end{array}$ & 3.58 & 4.00 & $* * *$ \\
\hline \multicolumn{5}{|c|}{ ASSESSMENT AND EXAMINATION } \\
\hline H6 & \begin{tabular}{|l|l|} 
Students can generate creative ideas and solutions. \\
\end{tabular} & 3.77 & 4.00 & **** \\
\hline $\mathrm{H} 7$ & Students can solve abstract problems creatively. & 3.62 & 4.00 & $*$ \\
\hline $\mathrm{H} 8$ & Students can develop new strategic approaches. & 3.77 & 4.00 & $*$ \\
\hline H9 & $\begin{array}{l}\text { Students are able to make decisions and understand the } \\
\text { circumstances and choices available. }\end{array}$ & 3.74 & 4.00 & $* * *$ \\
\hline H10 & $\begin{array}{l}\text { Students are able to identify risks and measure/analyse } \\
\text { those risks. }\end{array}$ & 3.97 & 4.00 & $* * *$ \\
\hline H11 & $\begin{array}{l}\text { Students are creative in creating/generating their own } \\
\text { jobs. }\end{array}$ & 4.03 & 4.00 & $* * *$ \\
\hline H12 & $\begin{array}{l}\text { Attempts to influence others to build a business network } \\
\text { in accordance with the opinion/idea of entrepreneurship. }\end{array}$ & 3.81 & 4.00 & $*$ \\
\hline \multicolumn{5}{|c|}{ DOMAIN OF INFORMATION MANAGEMENT SKILLS \& LIFELONG LEARNING } \\
\hline \multicolumn{5}{|c|}{ ASSESSMENT AND EXAMINATION } \\
\hline I1 & \begin{tabular}{|l|} 
Students decide freely on their own by taking into \\
account the basic methods, tools, materials and infor- \\
mation to solve the problem.
\end{tabular} & 3.97 & 4.00 & $*$ \\
\hline I2 & $\begin{array}{l}\text { Modules include requirements of complex technical or } \\
\text { professional or projects. }\end{array}$ & 3.62 & 4.00 & $* * *$ \\
\hline I3 & $\begin{array}{l}\text { Students learn independently and demonstrate their own } \\
\text { initiative. }\end{array}$ & 4.00 & 4.00 & $* * *$ \\
\hline I4 & $\begin{array}{l}\text { Students take responsibility for fulfilling job assign- } \\
\text { ments and learning. }\end{array}$ & 4.00 & 4.00 & $* * *$ \\
\hline I5 & $\begin{array}{l}\text { Students are able to plan autonomous solutions in a } \\
\text { complex and changing environment. }\end{array}$ & 3.74 & 4.00 & $* * *$ \\
\hline \multicolumn{5}{|c|}{ DOMAIN OF INTERDISCIPLINARY } \\
\hline \multicolumn{5}{|c|}{ The content of learning modules ... } \\
\hline $\mathrm{J} 1$ & \begin{tabular}{|l|l} 
Contains other field/discipline references. & \\
\end{tabular} & 3.84 & 4.00 & *** \\
\hline $\mathrm{J} 2$ & $\begin{array}{l}\text { Has interdisciplinary topic that needs to be identified } \\
\text { based on knowledge based from multiple disciplines. }\end{array}$ & 3.90 & 4.00 & $*$ \\
\hline $\mathrm{J} 3$ & \begin{tabular}{|l|l|} 
Explains the different terms used between fields. & \\
\end{tabular} & 4.06 & 4.00 & $* * *$ \\
\hline \multicolumn{5}{|c|}{ ASSESSMENT AND EXAMINATION } \\
\hline $\mathrm{J} 4$ & $\begin{array}{l}\text { Students present their solutions and ideas in detail to be } \\
\text { easily understood by the same individual of the profes- } \\
\text { sion or from other fields. }\end{array}$ & 3.74 & 4.00 & * \\
\hline
\end{tabular}

* No consensus

** Moderate

***High

After the data is analysed, refinement and item removal is done taking into account the views and assessments of experts and supervisors. The following is a summary of the results of the study:

Domain of knowledge (current): There were 18 items had been identified. From the analysis, 3 items were removed (items B5, B9 and B11).

Domain of practical skills: Domain of practical skills had 5 items. The majority of the panel members had a high level of consensus on several items (C2, C3 and C5) with the value of IQR 0 and 1. While one item (C1) gets the expert panels disagree- 
ment (no consensus), its IQR value is 2 as well as moderated consensus for item C4 where the value of IQR is 1.75 . But both items are agreed and maintained.

Domain of social skills \& social responsibilities: Domain of social skills \& social responsiveness had 8 items. Each item had been analysed and the majority of expert panels had consensus on the high level of IQR value which is 0 and 1 and the median value is at level 4. While D2 item is at moderate level where IQR value is 1.75 and median value at level 4 .

Domain of values, attitudes \& professionalism: For domain of value, attitudes \& professionalism there were 5 items had been identified. As a result of the analysis, 2 items were aborted (items E4 and E5). The majority of expert panels had consensus on a high level of IQR value which is 0 and 1 and the median value is at level 4. However, the mean values for E4 and E5 are low and this proves that expert panels had consensus to a high level to drop the item.

Domain of communication skills, leadership \& teamwork: The domain of communication skills, leadership \& teamwork had as many as 10 items. Based on the analysis, 3 items had been dropped (items F1, F5 and F8). The majority of the expert panels had consensus to a high level of IQR value of 0 and 1 and the median value is at level 4. However, expert panels had consensus on a high level to drop items for F1, F5 and F8 based on the low min value of the item.

Domain of problem solving skills \& scientific skills: A total of 8 items were identified for the domain of problem solving skills \& scientific skills. Some items were unacceptable (G1, G4, G5 and G6) but the median value is high. One item (G3) got a high consensus to be dropped.

Domain of management skills, entrepreneurship \& innovation: For the domain of management skills, entrepreneurship \& innovation it contains 12 items. Referring to the following table, there are 6 items $(\mathrm{H} 1, \mathrm{H} 5, \mathrm{H} 6, \mathrm{H} 9, \mathrm{H} 10$ and H11) which got a high consensus that the value of IQR is 0 and 1 and the median value is determined at 4. Whereas the other 6 items did not get the expert panels consensus where the value of IQR is 2. However, these six items were at an agreed and retained level.

Domain of information management skills \& lifelong learning: The information management \& lifelong learning domain had 5 items. The majority of expert panels had high level of consensus that the value of IQR is 0 and 1 and the median value is at stage 4 . But one item did not get expert panels consensus where the value of IQR is 2 .

Domain of interdisciplinary: Interdisciplinary domain had 5 items under evaluation and assessment. Referring to the following table 4.1 there are 2 items ( $\mathrm{J} 1$ and J3) which got a high consensus i.e. IQR value is 1 and the median value is determined as 4. While 2 items did not get expert panels consensus where the value of IQR is 2 . However, both of these items are in consensus and retained level.

\section{Conclusion}

This reviewer will make it easier for someone with the skills to pursue higher learning and to cultivate lifelong learning. This study is to meet the needs of human capital development in our country. Currently, students from the skills institute can 
hardly put themselves in an academic program. Students with skills have to undergo a very high admission requirement set by the university while at the same time have to start from the foundation and take very long learning time due to unrecognised previous knowledge. The evaluator of academic skills is a development of relevant qualification mobility and is a requirement to apply because it should be taken seriously as opportunities had to be given for those in the area of this skill to continue their studies at the academic level. All domains (9 domains) are very important in determining the content of the learning that will be used in the review of the equivalence between the fields of expertise to the academic. Items built by each domain are best suited for use.

\section{Acknowledgement}

This research was supported by the scholarship of Ministry of Higher Education (MyBrain15) and Universiti Tun Hussein Onn Malaysia (UTHM).

\section{$7 \quad$ References}

[1] Balli, B. \& Razally, W. (2011). Persidangan Kebangsaan Penyelidikan Dan Inovasi Dalam Pendidikan Dan Latihan Teknik Dan Vokasional. CIE-TVT 2011, 16th 17th November 2011, Pulau Pinang.

[2] Balasingam, U. (2015) Malaysian Qualification Framework: A Need to Revisit University of Malaya. Retrieved at http://eprints.um.edu.my/13545/1/MDP-99.pdf

[3] Kementerian Pengajian Tinggi Malaysia. (2007). Kerangka Kelayakan Malaysia. Putrajaya: Kementerian Pengajian Tinggi Malaysia. Retrieved at http://www.mqa.gov.my/porta 12012/default/bm/mqf.cfm https://doi.org/10.21315/mjms2019.26.4.15

[4] Kaprawi, N. (2011). Leveraging Accreditation of Prior Experiental Learning (APEL) for Human Capital Development. Universiti Tun Hussein Onn Malaysia.

[5] Maclean, R. \& Pavlova, M. (2013). Vocationalization of Secondary and Higher Education: Pathways to the World of Work. UNESCO-UNEVOC: Revisiting Global Trends in TVET.

[6] University of Worcester. (2011). Academic Regulations and Procedures: Policy and Principles for Accreditation of Prior Learning.

[7] Garnett, J., Portwood, D. \& Costley, C. (2004). Bridging Rhetoric and Reality: Accreditation of Prior Experiential Learning (APEL) in the UK. Bolton: University Vocational Awards Council.

[8] Müskens, W.; Wittig, W.; Tutschner, R.; Eilers-Schoof, A. (eds) (2013): MLI User Guide: Assessment of the Level of Competence Orientation. Bremen: Institut Technik und Bildung (ITB), Universität Bremen.

[9] National Qualifications Framework. 2009. European Frameworks: The Bologna Framework and the European Qualifications Framework. Retrieved at: http://www.nfq.ie/nfq/en/ frame_action/europe.html

[10] Kerangka Kelayakan Malaysia, MQF (2012). Garis Panduan Amalan Baik: Pengakreditan Pembelajaran Berasaskan Pengalaman Terdahulu.

[11] Konting, M. N. (2004). Kaedah Penyelidikan Pendidikan. 5th Edition. Kuala Lumpur: Dewan Bahasa \& Pustaka.

[12] Idris, N. (2013). Penyelidikan dalam pendidikan. McGraw-Hill Education.

[13] Chua. Y. P. (2008). Kaedah Penyelidikan. Serdang: Penerbitan Universiti Putra Malaysia. 
[14] Bond,T.G., \& Fox, C. M. (2007). Fundamental measurement in the human sciences. Chicago, IL:Institute for Objective Measurement

[15] Peck, R. \& Devor, J. L. 2012. Statistics: The Exploration and Analysis of Data. 7th Edition. United State: Richard Stratton.

[16] Wiersma, W. \& Jurs, S.G. 2009. Research Methods in Education. An Introduction. Ninth Edition. Boston: Pearson International Edition.

\section{Authors}

Noor Farhah Muzaimah Binti Mohd Amin is a postgraduate student currently studying on Faculty of Technical and Vocational Education at Universiti Tun Hussein Onn Malaysia, Batu Pahat, Johor in Malaysia.

Noraini Binti Kaprawi is a Professor at the Faculty of Technical and Vocational Education at Universiti Tun Hussein Onn Malaysia, Batu Pahat, Johor in Malaysia. She works also as a Principal Researcher Cluster Planning, Policy and Development of TVET/MyRIVET. She is a one of Malaysia Board of Technologists (MBOT) and as a trainer at National level on Outcome Based Education Trainer for Curriculum Developers of MoHE, AKEPT (Ministry of Higher Education Academic Leadership Academy) Master Trainer for Strategic Plan of Malaysian Higher Education and Trainer for Post Graduate Certificate in Learning and Teaching in Higher Education (MoHE)

Article submitted 2019-06-19. Resubmitted 2019-07-07. Final acceptance 2019-07-22. Final version published as submitted by the authors. 